\title{
Grime's CSR Strategies of Aquatic Macrophytes in Different Lagoon Lakes in Northern Turkey
}

\author{
Hacer Babur ${ }^{1}$, Burak Surmen ${ }^{2, *} \mathbb{D}$, Hamdi Guray Kutbay ${ }^{1}$
}

${ }^{1}$ University of OndokuzMayıs, Faculty of Arts and Sciences Department of Biology, 55139, Kurupelit-Samsun/TURKEY

${ }^{2}$ KaramanogluMehmetbey University, KamilOzdag Science Faculty, Department of Biology, 70200, Karaman/TURKEY

\section{How to cite}

Babur, H., Surmen, B., Kutbay, H.G. (2021). Grime's CSR Strategies of Aquatic Macrophytes in Different Lagoon Lakes in Northern Turkey. Turkish Journal of Fisheries and Aquatic Sciences, 21, 211-224. http://doi.org/10.4194/1303-2712-v21_5_01

\section{Article History}

Received 01 September 2020

Accepted 05 February 2021

First Online 17 February 2021

\section{Corresponding Author}

Tel.: +903382263831

E-mail: buraksurmen@gmail.com

\section{Keywords}

Biological diversity

Grime strategies

Lagoon

Macrophytes

Water traits

\begin{abstract}
In this study, CSR strategies, biological diversity and water traits were evaluated in three lagoon lakes (Liman, Cernek and Balık) which had different nutrient status in the Central Black Sea Region of Turkey. The most productive lake was Balık lake, while the lowest productive lake is Liman lake in the study area. Secondary strategies were found to be dominant in studied lakes. No species exhibit pure S-strategy in the present study. $\mathrm{pH}$, electrical conductivity, $\mathrm{P}$ and $\mathrm{NH}_{4}$ concentrations were found to be significant. However, total of nitrite- $\mathrm{N}$ and nitrate- $\mathrm{N}$ concentrations were not significant. EC and $\mathrm{pH}$ were associated with the species in Liman and Cernek lakes, respectively. However, $\mathrm{P}$ and $\mathrm{NH}_{4}$ concentrations were associated with the species in Balık lake according to canonical correspondence analysis. Significant correlations were found among chemical traits and biological diversity. pH was positively correlated with Shannon-Wiener index, while negatively correlated with Simpson and Berger-Parker indexes. No significant correlations were found between water $P$ concentrations and evenness. Our data supported intermediate disturbance hypothesis in the studied lakes.
\end{abstract}

\section{Introduction}

Plant functional traits mainly Grime's CSR strategies are reliably used in both terrestrial and aquatic communities, and these strategies have been used to define the niche of a particular species (Carvalho et al., 2020; Pierce et al., 2017). The main aim of the using of plant functional traits is to elucidate the links among plant species, habitat properties, distribution, and community assembly. The comparison of plant traits reveals valuable information about the functioning of aquatic communities with respect to their physical and chemical environment (Garbey et al., 2004; McCoy-Sulentic et al., 2017). Several studies reported that there were consistent trends in interspecific variation in traits across environmental gradients at regional to global scales (Chave et al., 2010; Kattge et al.,
2011; Wright et al., 2004). However, the extent to the relationships between ecological strategies and environmental traits apply to regional and local scales need to further exploration (Grime, 1979; McCoySulentic et al., 2017; Westoby \& Wright, 2006).

Aquatic ecosystems are of crucial interest for management and conservation purposes since the survival of aquatic macrophytes depends largely on local environmental factors and these ecosystems are very sensitive to changes in land-use patterns and the other anthropogenic pressures (Chappuis et al., 2014). Aquatic macrophytes are classified as "engineering species" because they have a major role in trophic and functional status of aquatic habitats. Capers et al. (2010) indicated that environmental conditions strongly influence aquatic plants. However, their ecological strategies against stress and disturbance factors and spatial and 
temporal patterns regarding water chemical traits are not adequately explained (Bolpagni et al., 2018).

Coastal lagoons are located between land and sea, and they are characterized by large fluctuations in physical and chemical conditions. They have been known as physically dominated systems with large salinity and are subjected to hydrodynamic fluctuations due to the intermittent sand barrier opening. They are dynamic ecosystems characterized by shallow waters isolated from the open sea by the presence of coastal barriers. They can be classified as an ecotone between marine, freshwater, and terrestrial ecosystems (Christia et al., 2018; Rodríguez-Gallego et al., 2015). The Kizılırmak Delta is situated in the north of Turkey $\left(41^{\circ} 30^{\prime}-41^{\circ} 45^{\prime} \mathrm{N}\right.$; $\left.35^{\circ} 43^{\prime}-36^{\circ} 08^{\prime} \mathrm{E}\right)$ in the Black Sea Region (Figure 1). The total area of this delta is $56.000 \mathrm{ha}^{-1}$, and $21.700 \mathrm{ha}^{-1}$ of which are included brackish lakes were classified as Ramsar Site under the Ramsar Convention (DSI, 2017). In Kızılırmak Delta, there are different lagoons which subjected to various disturbance factors such as sand extraction, agricultural facilities, wastewater disposal etc.

This study is aimed to classify macrophytes with respect to CSR strategies according to two schemes in three lagoons with different environmental features. The second aim of this study is to evaluate the water chemistry of studied lagoons and relationships among ecological strategies and biological diversity. In addition to this, the validity of the intermediate disturbance hypothesis in three lagoon lakes was also studied.

\section{Material and Methods}

The coastal length of the delta is approximately 73 $\mathrm{km}$. The study area includes three lagoons which separated from the Black Sea by a sand bed. The lakes are formed by long term coastal drift. A connection is formed with the Black Sea, especially during autumn. So the total area of the lakes reached to 9.250 ha during autumn although their area covered a 2.720 ha area (Bilgin et al., 2003; Ozturk et al., 2015).

Mediterranean climate is seen in the study area, and summer drought occurred from June to the onset of September. Summer rainfall is $105 \mathrm{~mm}$, while annual precipitation and temperature are $672.4 \mathrm{~mm}$, and $13.5^{\circ} \mathrm{C}$, respectively. Maximum temperature of the hottest month and minimum temperature of the coldest month are $30.1^{\circ} \mathrm{C}$ and $2.9^{\circ} \mathrm{C}$, respectively. Aridity index is 3.4, and pluviometric quotient is 85.4. Precipitation regime is Eastern Mediterranean (Sürmen et al., 2019).

There are three lagoon lakes in the study area, namely Liman lake, Cernek lake and Balık lake. One of the coastal shallow lakes Liman lake (Ulu lake) is situated in the western part of the Kızılırmak Delta and covers a 1.380 ha area. Balık lake is connected to the Black Sea, and as a result of the salt content is increased. Cernek lake is a relatively eutrophic shallow lake, and the lower layer contains clayey soils. Extensive agricultural activities are carried out on the western borders of the lake, whereas on the east side, many canals are connected to the sea. Waste water was discharged by a



Figure 1. A. Map of Turkey, B. Map of Kızılırmak Delta in 1885, C. Map of Kızlırmak Delta in 2019. 
channel (Badut Channel) in previous years, but this connection was interrupted after the construction of a wastewater treatment plant (Can \& Taş, 2012). Balık lake located to the east of the study area. It is the largest lake among the lakes and is the farthest from the sea among the lakes as a result of changes in the coastline. The environment of the lake is under heavy pressure in terms of settlements and agricultural activities.

Parallel transects were laid and evenly placed around the studied lakes. 10 parallel transects of $5 \mathrm{~m}$ width ran perpendicular to the shore to the maximum depth of vegetation cover for each lake. 60 sampling quadrats of $4 \mathrm{~m}^{2}$ separated by $50 \mathrm{~m}$ were regularly distributed along each transect. All samplings were performed from April 2017 to Aprill 2018. For each quadrat cover-abundance values of the species were determined according to Braun-Blanquet method. For the analysis, the Braun- Blanquet scale was transformed on \% values as proposed by Van Der Maarel (1979). The cover-abundance symbols of the Braun-Blanquet scale $(1,2,3,4$ and 5$)$ were replaced by values according to van der Maarel: 1, 2, 3, 5, 7, 8, and 9, respectively (Agır et al., 2014; Yalçin et al., 2004).

According to Grime's CSR model, 3 primary strategies, namely competitive (C), stress-tolerant (S), and ruderal $(R)$, and main secondary strategies (CS: competitive stress-tolerant; CR: competitive ruderal; SR: stress-tolerant ruderal; CSR: competitive stress-tolerant ruderal) are classified (Hodgson et al., 1999). CSR values of species were determined using an Excel program according to two scheme (Hodgson et al., 1999; Pierce et al., 2013) Firstly, the calculation of CSR coordinates was performed for the aquatic species, following the method of (Grime et al., 1989). This method uses the eight plant characteristics. These are specific leaf area, leaf area, lateral spread, leaf dry weight, leaf dry matter content, flowering start, flowering period, and canopy height. Secondly, we used Pierce et al. (2013) scheme. They made some revisions on original Grime's classification system due to some deficiencies in the determination of some criteria.

The Shannon-Wiener, Simpson and Berger-Parker diversity and evenness indexes have been widely used to determine alpha diversity in ecological studies. Shannon-Wiener and Simpson indexes are used of species diversity for aquatic plant communities (Metian et al., 2020; Wu \& Ding, 2020). To assess the plant diversity of the aquatic plant communities of studied lagoon lakes, the following five $\alpha$-species diversity indices were calculated (Higuti et al., 2007; Wu et al., 2016, 2017).

$$
\text { Shannon }- \text { Wiener diversity index }\left(H^{\prime}\right)=-\sum_{i=1}^{S} p i * \ln * p i
$$

Where " $\mathrm{S}$ " is the total number of species and $\mathrm{Pi}$ is the relative cover of " $\mathrm{i}$ "th species. Evenness was calculated as:

$$
\text { Shannon - Wiener evenness index }(J)=\frac{H^{\prime}}{H^{\prime} \max }
$$

where $\mathrm{Hmax}=\ln \mathrm{s}$

where " $s$ " is the total number of species, and "pi" is the relative cover of " $\mathrm{i}$ " th species

Simpson diversity and evenness were calculated the following formulas (Smith \& Wilson, 1996):

$$
\text { Simpson diversity index }(D)=1 \sum_{i=1}^{s} p i^{2}
$$

Where " $\mathrm{S}$ " is the total number of species and "pi" is the relative cover of the " $\mathrm{i}$ " th species: Evenness was also calculated for Simpson index.

$$
\text { Simpson evenness diversity }(E p)=\frac{D}{D \max }=\frac{1}{\sum_{i=1}^{s} p i^{2}} \times \frac{1}{s}
$$

Where "Ep" is the evenness value according to Simpson index, " $D$ " is Simpson diversity index, " $s$ " is a number of species, and "pi" is the relative cover of the "i" th species (Magurran \& Mc Gill, 2011).

Berger-Parker diversity index (d) was calculated the following formula (Berger \& Parker, 1970);

Berger-Parker diversity index $(\mathrm{d})=\mathrm{Nmax} / \mathrm{N}$

where " $d$ " Berger-Parker index; " $N$ " is a total number of species in a plot, and, "Nmax" is the number of individuals of the most abundant species. Reciprocal of "d" values were used (Agır et al., 2016; McCarthy \& Magurran, 2004).

Twelve water samples were taken from each of the studied lakes. Water samples were collected at the deepest location, i.e., near the outlet of each lake and at the same depths, and these were stored at $3^{\circ} \mathrm{C}$ until analyzed for $\mathrm{pH}$, alkalinity, conductivity, and total phosphorus (Arthaud et al., 2012; Capers et al., 2010). Ammonia-nitrogen $\left(\mathrm{NH}_{4}\right)$ concentration was determined by using the LAMBDA $265^{\mathrm{TM}}$ UV/Vis spectrophotometer. Total of nitrite- $\mathrm{N}$ and nitrate- $\mathrm{N}$ concentrations were obtained from General Directorate of State Hydraulic WorksData (DSI, 2017).

Data of each lake were analysed for normality by using Kolmogorov-Smirnov test, and so log-transformed values of TDS, $N$, total of nitrite- $N$ and nitrate- $N$ concentration in all lakes were used for statistical analysis. We identified the plant communities using a two-way indicator species analysis (TWINSPAN). This analysis has been proposed by Roleček et al. (2009). TWINSPAN, at each step, divides only the most heterogeneous cluster of the previous hierarchical level. Thus, TWINSPAN results in vegetation units of similar internal heterogeneity (Brown et al., 2013). Canonical correspondence analysis (CCA) was performed to detect in plant species composition in studied lakes and species-environment relations (Henderson \& Seaby, 1999) software programs. One-way ANOVA was also performed to show the difference among lakes in terms of water samples and diversity indexes. Tukey's significant difference (HSD) test was used to rank means following the analysis of variance (IBM, 2012). 


\section{Results}

TWINSPAN showed that three different communities were found in studied lagoon lakes. The number of characteristic species of these communities was increased depending on the distance from the sea (Figure 2). Besides, the average density of the species is given as a percentage for each lake (Table 1). The character species with a density of more than 10 percent are as follows: Sparganium erectum L. is in the Liman lake, Carex nigra (L.) Reichard, Ceratophyllum demersum L., Nymphaea alba L., Ranunculus trichophyllus Chaix. are in Cernek lake, and Butomus umbellatus L. and Juncus acutus L. species are in Balık lake. Finally, TWINSPAN revealed that Balık and Cernek lakes were different from Liman lake.

Six chemical traits were calculated for each lagoon lakes. $\mathrm{pH}$ values were found to be highest in Cernek lake and were found to be lowest in Liman lake. Mean EC values in Liman and Cernek were higher than Balık lake. Mean Nitrogen concentrations were found similar in Cernek and Balık lakes while it was found to be lowest in Liman lake. Mean P concentration was highest in Balık lake. Mean $\mathrm{NH}_{4}$ was the highest in Balık lake. Mean $\mathrm{NO}_{2}-$ $\mathrm{NO}_{3}$ concentration was found to be the highest in Balık lake. Additionally, we found statistical differences among lakes (Table 2).

27.84 and $20.86 \%$ of the variation in axis 1 and axis

2, respectively, was explained by environmental conditions. Cumulative variation was found to be 27.84 and 48.71, respectively. Species/environment scores were found to be significant. Intraset correlation coefficients of $\mathrm{pH}, \mathrm{P}, \mathrm{NH}_{4}$ and total $\mathrm{NO}_{2}-$ $\mathrm{NO}_{3}$ concentrations were found to be negatively significant in axis 1 , while EC was found to be positively significant in axis 1 . In axis 2, $\mathrm{pH}$ and $\mathrm{EC}$ were found to be positively significant (Table 3 ). Liman and Cernek lakes were located on the positive side of the CCA diagram, while Balık lake was located on the negative side of the CCA diagram. EC was associated with the species in Liman and Cernek lake. $\mathrm{P}$ and $\mathrm{NH}_{4}$ concentrations were associated with the species in Balık lake. A gradient was formed with respect to salinity from Balık to Liman lake (Figure 3).

CSR values of species and community levels were calculated using two scheme. Firstly, 10 different strategies belonging to the primary, secondary and transient level were calculated for species according to Grime et al. (1989) scheme. These are given in detail in figure 4 . It has been found that similar species have different strategies, especially in the lakes studied. For example; Potamogeton nodosus Poiret has got CR strategy in Cernek and Balık lake, but it has got $C$ strategy in Liman lake. And Potamogeton pectinatus $\mathrm{L}$. (Figure 4). At the community level, three different strategies were determined. Liman lake is C/CR strategy, Cernek lake is CR/CSR, and last Balık lake is C/CSRstrategy (Figure 5).

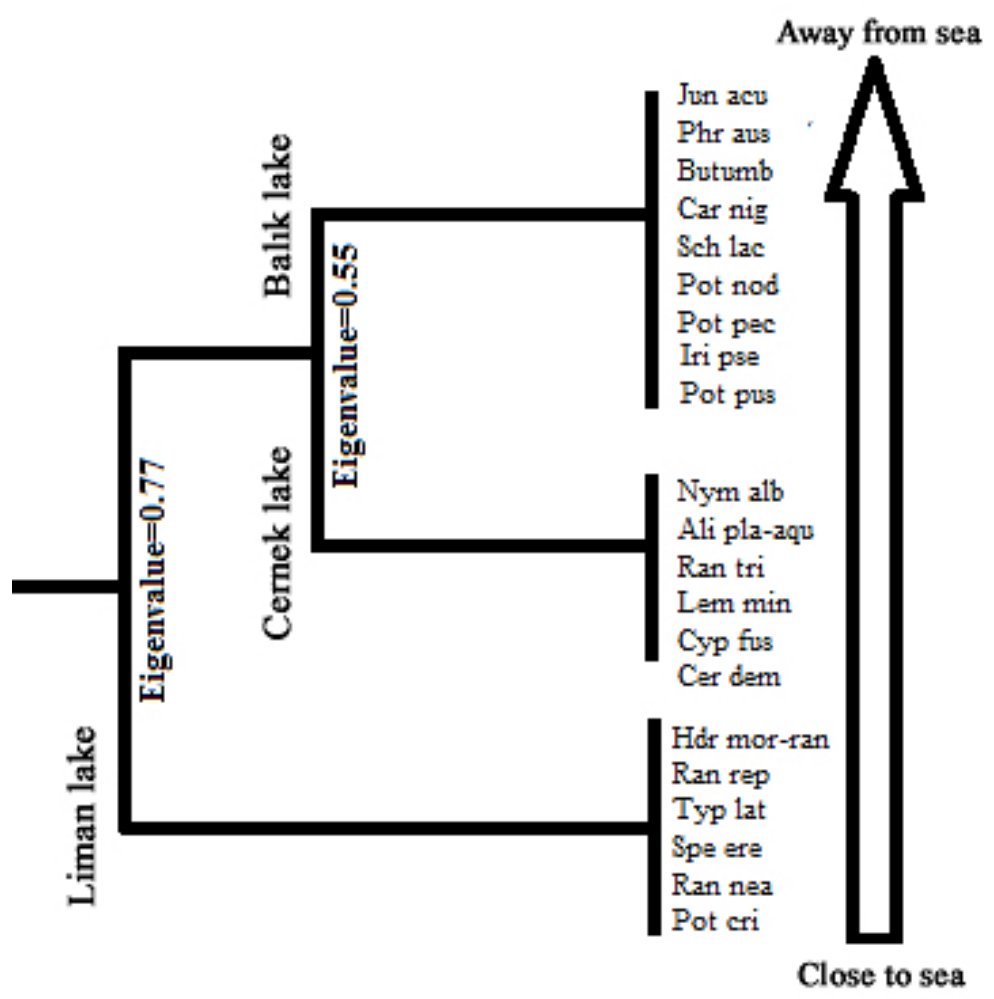

Figure 2. TWINSPAN analysis of studied lagoon lake communities. Species abbreviations: Ali pla-aqu; Alisma plantago L. subsp. aquatica, But umb; Butomus umbellatus L., Car nig; Carex nigra (L.) Reichard, Cer dem; Ceratophyllum demersum L., Cyp fus; Cyperus fuscus L., Hyd mor-ran; Hydrocharis morsus-ranae L., Iri pse; Iris pseudacorus L., Jun acu; Juncus acutus L., Lem min; Lemna minor L. Nym alb; Nymphaea alba L. Phr aus; Phragmites australis (Cav.) Trin. ex Steudel, Pot cri; Potamogeton crispus L., Pot nod; Potamogeton nodosus Poiret, Pot pec; Potamogeton pectinatus L., Pot pus; Potamogeton pusillus L., Ran nea; Ranunculus neapolitanus Ten., Ran rep; Ranunculus repens L., Ran tri; Ranunculus trichophyllus Chaix., Sch lac; Schoenoplectus lacustris (L.) Palla subsp. lacustris, Spa ere; Sparganium erectum L., Typ plat; Typha latifolia L. 
Secondly, 8 different strategies belonging to the primary, secondary and transient level were calculated for species, according to Pierce et al. (2013) scheme. In addition, 4 new strategy types have been identified. These are $R, R / C R, S R$ and S/CSR (Figure 6). At the community level, two different strategies were determined. Liman and Balık lake are C/SC strategy, Cernek lake is C/CSR strategy (Figure7).

When the types SLA (specific leaf area) values are examined, the average values of the species are similar to each other except for a few species Cyperus fuscus $\mathrm{L}$. in Cernek lake and Alisma plantago L. subsp. aquatica in Balık lake). When the leaf dry weight (LDW) and $\mathrm{pH}$ graphs are examined, it is seen that the species in Liman and Balık lake have similar values. Finally, when the life span (LS) features of the species were examined, it was determined that they mostly had two features. These are compactly tufted about a single axis, thickened rootstock present (3) and widely creeping, $>79 \mathrm{~mm}$ between ramets (6). Only Lemna minor L. has different lateral spread (4: shortly creeping, $<40 \mathrm{~mm}$ between ramets) (Figure 8).
The highest Shannon-Wiener indexes ( $\mathrm{H}$ and $\mathrm{J}$ ) were found in Cernek lake, while the lowest ShannonWiener indexes ( $\mathrm{H}$ and $\mathrm{J}$ ) were found in Balık and Liman lakes, recpectively. The highest Simpson indexes ( $D$ and 1/D) were found in Balık and Cernek lakes, repectively (Table 4).

Shannon's biodiversity was correlated with water traits except for total $\mathrm{P}$ concentration. However, Shannon's evenness was only correlated with $\mathrm{pH}$ and total $\mathrm{N}$ concentration. Simpson and Berger-Parker diversity indexes were correlated with water traits except for $\mathrm{P}$ (Table 5).

\section{Discussion}

$\mathrm{pH}$ values were found to be 7.80-9.00 in studied lagoon lakes. Similar values were found at coastal saline ecosystems in Turkey (Eskandri, 2014; Özdemir, 2019). Eskandari (2014) calculated pH values of Çamaltı, Ayvalık and Gökçeada lagoon lakes range from 7.62 to 9.32. Fener lake (Kocaeli) had 8.1-8.4 pH values (Morkoyunlu Yüce et al., 2017). pH values of Simenit

Table 1. The mean abundance of the species in Lagoon lakes.

\begin{tabular}{|c|c|c|c|}
\hline \multirow{2}{*}{ Species } & \multicolumn{3}{|c|}{ Mean abundance (\%) } \\
\hline & Liman Lake & Cernek Lake & Balık Lake \\
\hline Alisma plantago L. subsp. aquatica & - & 4.4 & 3.1 \\
\hline Butomus umbellatus L. & 4.4 & 4.7 & 18.1 \\
\hline Carex nigra (L.) Reichard & 4.8 & 13.1 & 6.4 \\
\hline Ceratophyllum demersum L. & 3.4 & 10.1 & - \\
\hline Cyperus fuscus L. & - & 2.3 & - \\
\hline Hydrocharis morsus ranae $\mathrm{L}$. & 3.4 & - & 2.1 \\
\hline Iris pseudacorus L. & - & - & 9.4 \\
\hline Juncus acutus L. & 12.6 & 14.8 & 13.6 \\
\hline Lemna minor $\mathrm{L}$. & - & 2.7 & - \\
\hline Nymphaea alba L. & - & 12.1 & 12.4 \\
\hline Phragmites australis (Cav.) Trin. ex Steudel & 12 & 3.5 & 2.1 \\
\hline Potamogeton crispus L. & 8.2 & & - \\
\hline Potamogeton nodosus Poiret & 7.2 & 2.6 & 2.2 \\
\hline Potamogeton pectinatus L. & 8 & 9.1 & 5.1 \\
\hline Potamogeton pusillus L. & - & - & 3 \\
\hline Ranunculus neapolitanus Ten. & 3.7 & - & - \\
\hline Ranunculus repens $\mathrm{L}$. & 3.4 & 4.8 & - \\
\hline Ranunculus trichophyllus Chaix. & - & 11.3 & 4.1 \\
\hline Schoenoplectus lacustris (L.) Palla subsp. lacustris & 12.2 & 3.7 & 4.3 \\
\hline Sparganium erectum $\mathrm{L}$. & 11.9 & & - \\
\hline Typha latifolia L. & 4.4 & - & 13.6 \\
\hline
\end{tabular}

Table 2. The chemical traits of Lagoon lakes (Means followed by the different letters in the same line are significantly different at the 0.05 level according to Tukey's HSD test).

\begin{tabular}{|c|c|c|c|}
\hline Water chemical traits & Liman Lake & Cernek Lake & Balık Lake \\
\hline $\mathrm{pH}$ & $8.22 \pm 0.11 \mathrm{c}$ & $8.73 \pm 0.07 a$ & $8.46 \pm 0.04 b$ \\
\hline $\mathrm{EC}(\mathrm{mS})$ & $4.16 \pm 0.43 a$ & $3.87 \pm 0.36 b$ & $0.16 \pm 0.00 c$ \\
\hline Nitrogen concentration (\%) & $0.65 \pm 0.07 b$ & $1.75 \pm 0.23 a$ & $1.77 \pm 0.43 a$ \\
\hline Phosphorus concentration (\%) & $0.04 \pm 0.01 c$ & $0.09 \pm 0.01 b$ & $0.34 \pm 0.10 a$ \\
\hline Ammonia-nitrogen concentration (mg/L) & $0.39 \pm 0.04 c$ & $0.96 \pm 0.12 b$ & $3.11 \pm 0.23 a$ \\
\hline Nitrite-N and nitrate- $N$ concentrations $(\mu \mathrm{g} / \mathrm{L})$ & $0.06 \pm 0.02 c$ & $0.63 \pm 0.31 b$ & $0.78 \pm 0.16 a$ \\
\hline
\end{tabular}


Table 3. Intraset correlation coefficients of chemical traits

\begin{tabular}{lcc}
\hline & Axis 1 & Axis 2 \\
\hline $\mathrm{pH}$ & -0.556 & 0.667 \\
$\mathrm{EC}$ & 0.624 & 0.615 \\
$\mathrm{P}$ & -0.444 & -0.343 \\
$\mathrm{NH}_{4}$ & -0.774 & -0.518 \\
$\mathrm{NO}_{2}-\mathrm{NO}_{3}$ & -0.426 & 0.149 \\
\hline
\end{tabular}

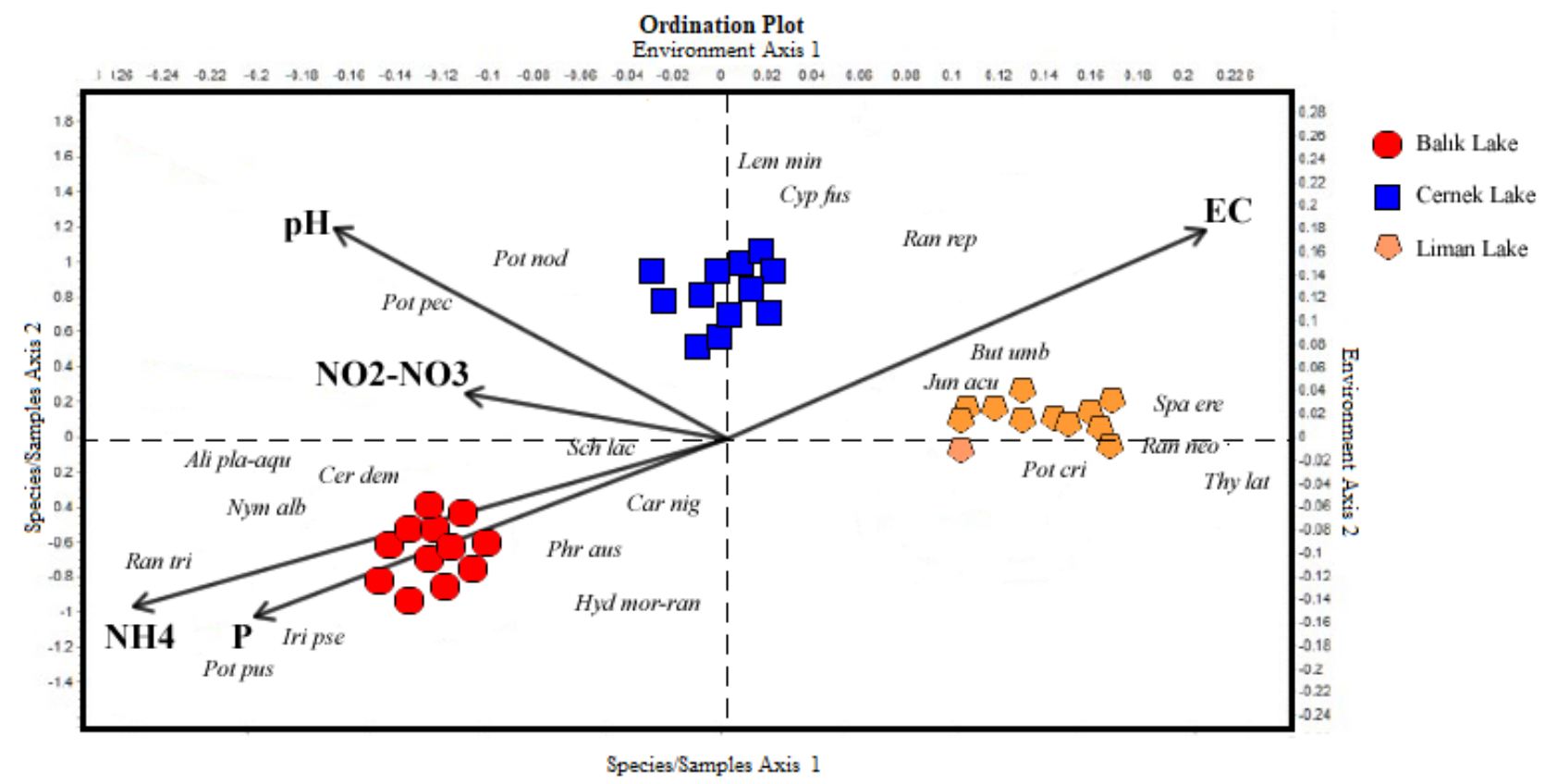

Figure 3. CCA ordination of chemical traits in studied lakes (see figure 2 for species abbreviations).

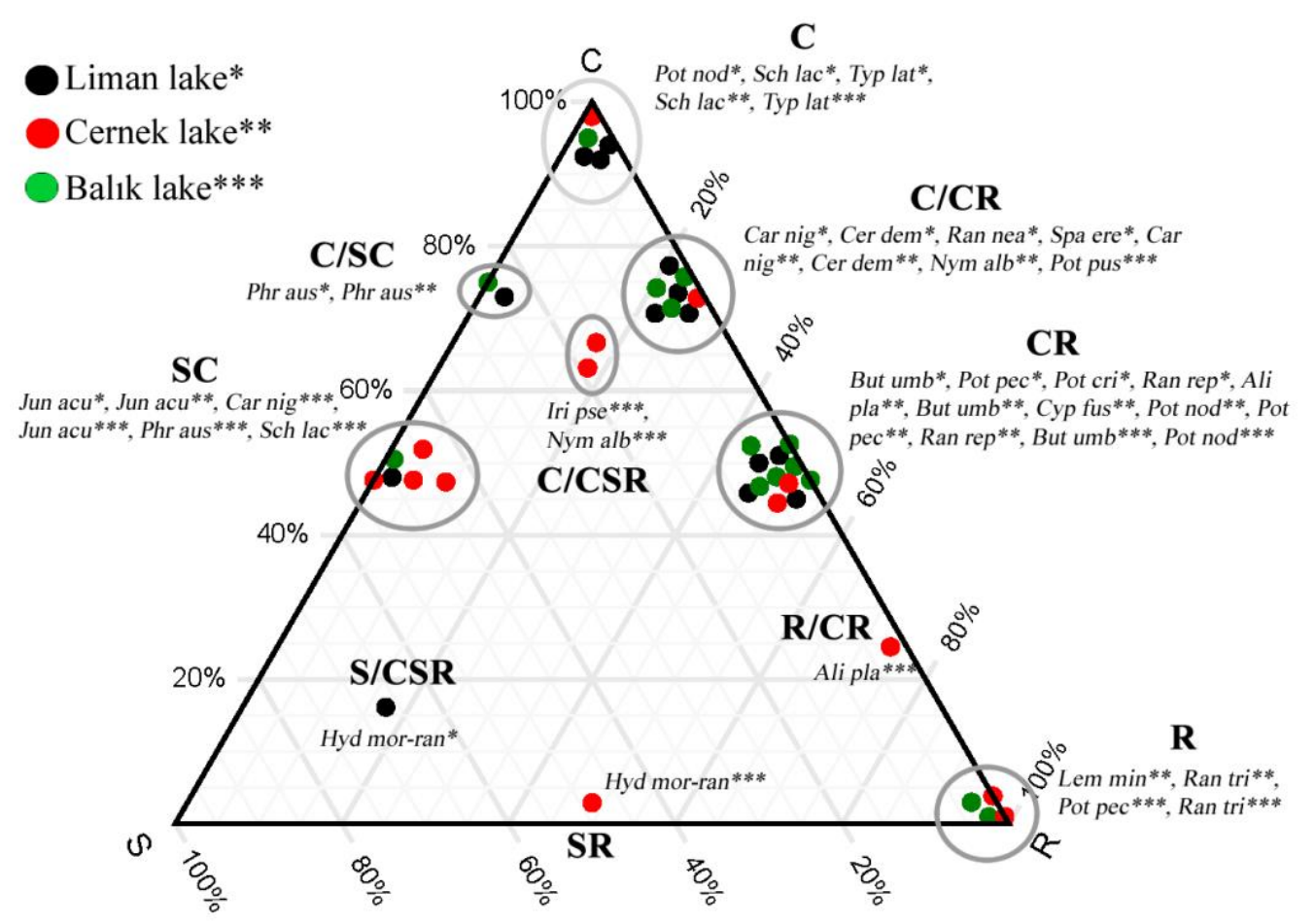

Figure 4. CSR (C: competitive, S: stress-tolerant, R: ruderal, CR: competitive ruderal, SC: competitive stress-tolerant, SR: stresstolerant ruderal CSR: competitive stress-tolerant ruderal) strategies of species according to Grime scheme. See figure 2 for species abbreviations. 


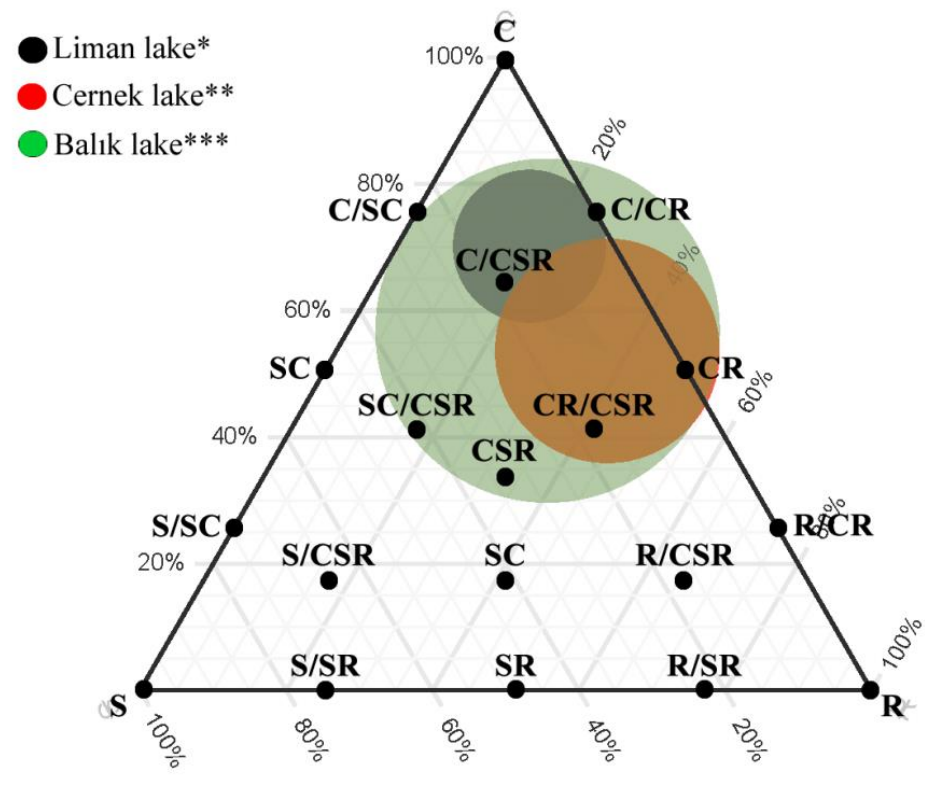

Figure 5. CSR (C: competitive, S: stress-tolerant, R: ruderal, CR: competitive ruderal, SC: competitive stress-tolerant, SR: stresstolerant ruderal CSR: competitive stress-tolerant ruderal) community strategy of lagoon lakes according to Grime scheme.



Figure 6. CSR (C: competitive, S: stress-tolerant, R: ruderal, CR: competitive ruderal, SC: competitive stress-tolerant, SR: stresstolerant ruderal CSR: competitive stress-tolerant ruderal) strategies of species according to Pierce et al's scheme. See figure 2 for species abbreviations.

lake were found at 7.65 and 8.75 (Ersanli \& Gönülol, 2006; Ersanli \& Gonulol, 2007). According to and Lacoul \& Freedman (2006) the studied lakes were classified as hardwater habitats because $\left(>0.4 \mathrm{meq} / \mathrm{I} \mathrm{HCO}_{3}{ }^{-}\right)$, with high concentrations of carbonates and $\mathrm{pH}>7$. Species of submerged hydrophytes that reach their greatest abundance in hardwater lakes include C. demersum, P. crispus, P. nodosus, P. pectinatus (Lacoul \& Freedman,
2006). If $\mathrm{pH}$ in aquatic habitat ranges from 6.0 to 9.2 most of the carbon is present as bicarbonate, and these habitats have been classified as nutrient-rich because of extra carbon (Alahuhta et al., 2017; Bolpagni et al., 2018; CAPERS et al., 2010; Riis \& Biggs, 2001). The influence of alkalinity is likely related to the different forms of carbon utilized by macrophytes in photosynthesis (Alahuhta, 2015). 


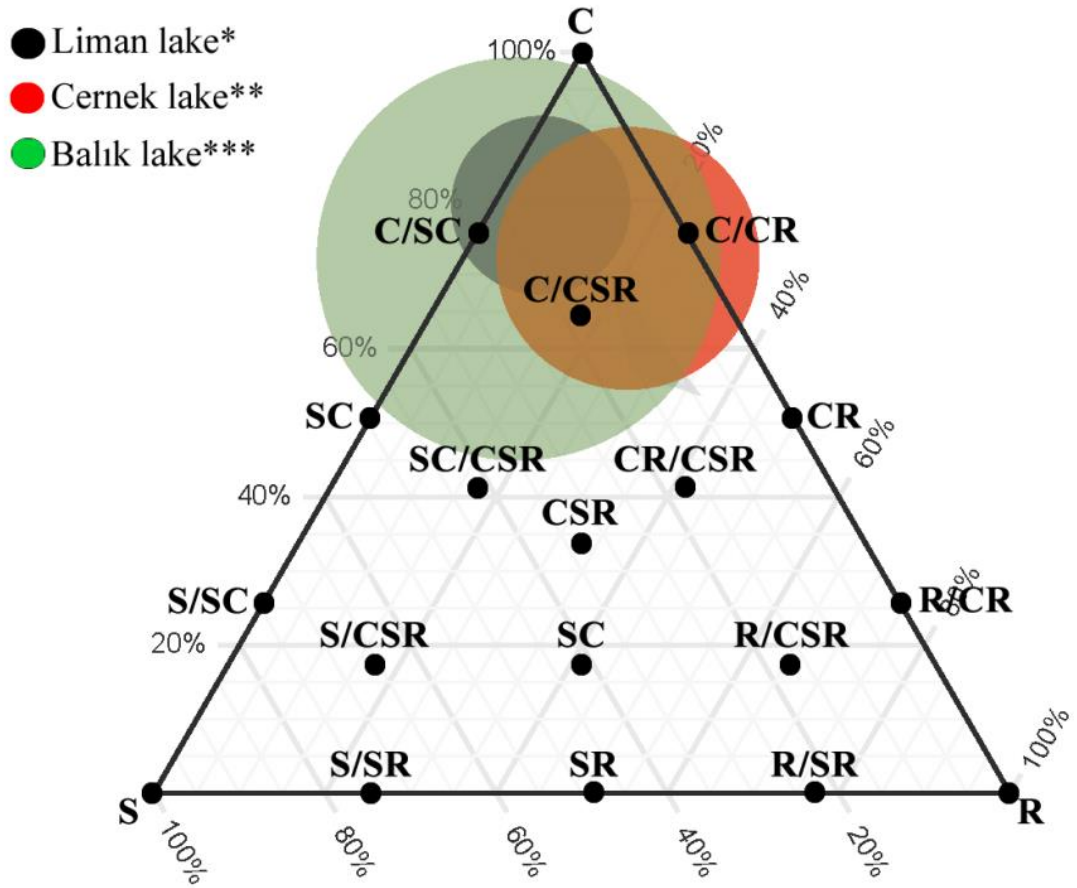

Figure 7.CSR (C: competitive, S: stress-tolerant, R: ruderal, CR: competitive ruderal, SC: competitive stress-tolerant, SR: stresstolerant ruderal CSR: competitive stress-tolerant ruderal) community strategy of lagoon lakes according to Pierce et al's scheme.



Liman

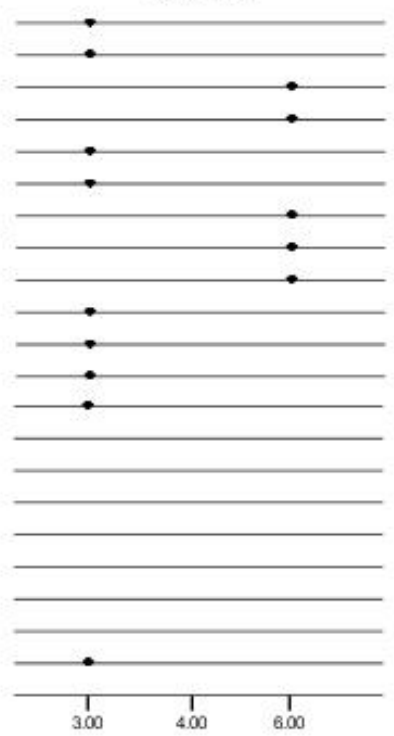

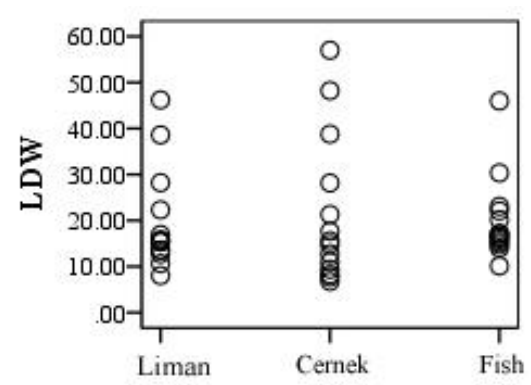

Cernek

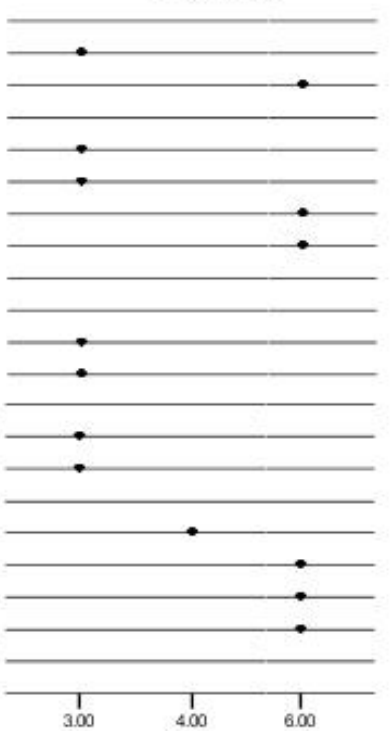

Lateral spread

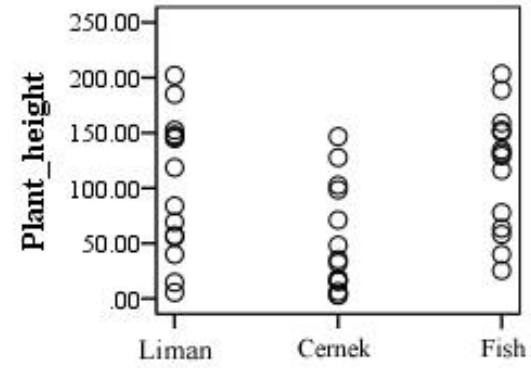

Fish

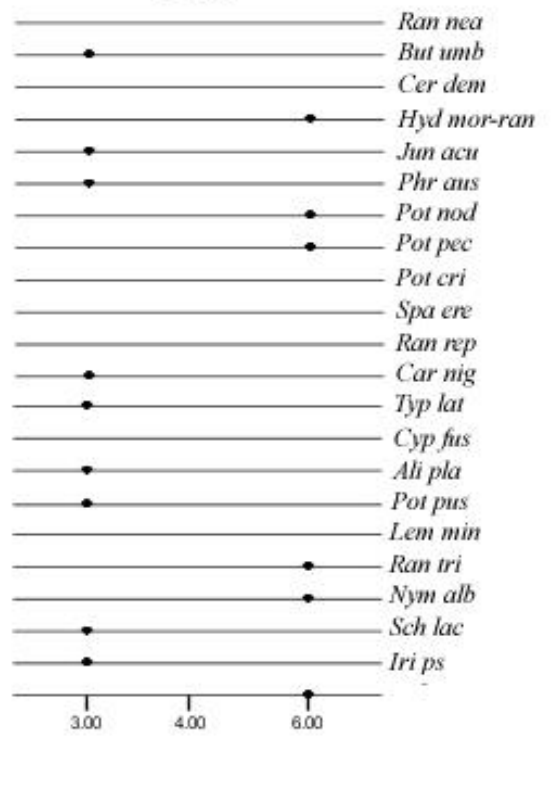

Figure 8. Some features of species using to calculate strategies. 
Table 4. Statistical evaluation of diversity indexes by One-way ANOVA test (Means followed by the different letters in the same line are significantly different at the 0.05 level according to Tukey's HSD test).

\begin{tabular}{|c|c|c|c|}
\hline Diversity index & Liman Lake & Cernek Lake & Balık Lake \\
\hline Shannon-Wiener diversity index $\left(\mathrm{H}^{\prime}\right)$ & $1.25 \pm 0.21 c$ & $1.47 \pm 0.05 a$ & $1.21 \pm 0.16 \mathrm{~d}$ \\
\hline Shannon-Wiener evenness index (J') & $0.93 \pm 0.09 c$ & $0.97 \pm 0.02 a$ & $0.94 \pm 0.06 \mathrm{ab}$ \\
\hline Simpson diversity index (D) & $0.04 \pm 0.00 a$ & $0.02 \pm 0.00 b$ & $0.05 \pm 0.00 \mathrm{a}$ \\
\hline Simpson evenness index (1/D) & $23.64 \pm 1.26 b$ & $47.23 \pm 2.65 \mathrm{a}$ & $21.79 \pm 0.99 b$ \\
\hline Berger-Parker diversity index (d) & $0.10 \pm 0.00 a$ & $0.07 \pm 0.00 \mathrm{~b}$ & $0.10 \pm 0.00 \mathrm{a}$ \\
\hline
\end{tabular}

Table 5. Correlations between lake features and biodiversity results

\begin{tabular}{lccccc}
\hline & \multicolumn{2}{c}{ Correlations } \\
\hline & Shannon H' & Shannon J' & $\begin{array}{c}\text { Simpson } \\
\text { (D) }\end{array}$ & $\begin{array}{c}\text { Simpson } \\
\text { (1/D) }\end{array}$ & $\begin{array}{c}\text { Berger-Parker } \\
\text { (d) }\end{array}$ \\
\hline $\mathrm{pH}$ & $0.549^{* *}$ & $0.601^{* *}$ & $-0.489^{* *}$ & $0.520^{* *}$ & $-0.364^{*}$ \\
$\mathrm{EC}$ & $0.546^{* *}$ & 0.128 & $-0.482^{* *}$ & $0.432^{* *}$ & $-0.417^{*}$ \\
$\mathrm{~N}$ & $0.457^{* *}$ & $0.363^{*}$ & -0.171 & 0.222 & -0.112 \\
$\mathrm{P}$ & -0.210 & -0.032 & 0.274 & -0.236 & 0.177 \\
$\mathrm{NH} 4$ & $-0.433^{* *}$ & -0.012 & $0.409^{*}$ & $-0.349^{*}$ & $0.376^{*}$ \\
$\mathrm{NO}_{2}-\mathrm{NO}_{3}$ & $0.373^{*}$ & 0.249 & -0.059 & 0.106 & -0.076 \\
\hline
\end{tabular}

**. Correlation is significant at the 0.01 level (2-tailed).

*. Correlation is significant at the 0.05 level (2-tailed).

The productive status of studied lakes was decreased from Fish lake to Liman lake. Total $\mathrm{N}, \mathrm{NH}_{4}$ and $P$ concentrations were lower as compared to other lakes in Liman lake. Morkoyunlu Yüce et al. (2017) found that total $\mathrm{N}$ concentrations were between $1.3-2.7 \mathrm{mg} / \mathrm{l}$ in Fener lagoon lake. $\mathrm{NH}_{4}$ concentrations of lagoon lakes were determined at low levels (Eskandari, 2014). Nitrogen and phosphorous are generally considered to be one of the most limiting elements in terrestrial and aquatic environments (Lukács et al., 2017). Totat nitrite$\mathrm{N}$ and nitrate- $\mathrm{N}$ concentrations of studied lakes in the Black Sea were higher than the lagoon lakes of Aegean and Mediterranean sea (Ersanli \& Gönülol, 2006; Ersanli \& Gonulol, 2007; Eskandari, 2014; Morkoyunlu Yüce et al., 2017; Özdemir, 2019). Electrical conductivity (EC) was found to be significant in both axis 1 and 2. Salinity plays a key role in macrophytic species in studied lagoon lakes (Christia et al., 2018).

Shannon's diversity was found to be low in Balık lake, and $\mathrm{N}$ and $\mathrm{P}$ concentrations were high in Balık lake. According to Grime (2002), high nutrient concentrations should result in a decrease in diversity and richness (Tyrrell, 2015). Significant correlations were found among chemical traits and biological diversity. $\mathrm{pH}$ was positively correlated with Shannon-Wiener index, while negatively correlated with Simpson and Berger-Parker indexes. Chytrý et al. (2003) and Schuster \& Diekmann (2003) were found positive correlations, while Gaberščik et al. (2018) were found negative correlations between $\mathrm{pH}$ and biological diversity. However, no significant correlations were found between water $P$ concentrations and evenness. Arthaud et al. (2012) found that total phosphorus concentration was associated with decreased diversity but not evenness. High $\mathrm{P}$ concentrations were found in Balık lake, where the lowest biological diversity was found. High $P$ concentrations lead to luxurious growth of some selected aquatic species, while slow-growing species negatively affected and as a result of these factors biological diversity was reduced. Water chemical traits affect the species richness of macrophytes in a complex fashion, and their individual effects can be challenging (Alahuhta, 2015; Gaberščik et al., 2018).

Many species in studied lakes exhibit secondary strategies according to two scheme were used. When we used to Grime et al. (1989) scheme, three species in Liman lake (Potamogeton nodosus Poiret, Schoenoplectus lacustris (L.) Palla subsp. lacustris and Typha latifolia L.) and two species (S. lacustris subsp. lacustris and T. latifolia) in Balık lakes exhibit pure Cstrategy. L. minor and R. trichophyllus in Cernek lake and $P$. pectinatus and $R$. trichophyllus in Balık lake exhibit pure R.-strategy. When we used to Pierce et al. (2013) scheme, five species in Liman lake (B. umbellatus $L$, $P$. pectinatus, $P$. nodosus, $S$. erectum and $T$. latifolia), three species (B. umbellatus, $N$. alba and $P$. nodosus) in Cernek lake and two species ( $B$. umbellatus and T. latifolia) in Balık lake exhibit pure C-strategy. The lower nutrient status may restrict the growth of competitive species (Kennedy \& Murphy, 2003). Greulich \& Bornette (1999) also stated that intermediate secondary strategies are widespread in habitats where no single environmental factor predominated. Any of the species exhibit S-strategy in the present study. Grime (1979) and Kautsky (1988) suggested that hydrophytes may not include stress tolerators because no species in freshwater habitats to persist at high disturbance frequency and low resource supply (Pierce et al., 2012; Riis \& Biggs, 2001). 
As production increases in an aquatic ecosystem, C-strategists become dominant, and species diversity was decreased. Species diversity was found to be low in Balık lake, and C-strategy was found at the community level. High productivity and low disturbance lead to the dominancy of C-strategists with floating leaves. Low productivity causes the increasing dominancy of Sstrategists without disturbance frequency (Arthaud et al., 2012; Kautsky, 1988; Murphy et al., 1990).

According to both scheme, it is seen that species with C-strategy are more in the Liman lake. Grime (2002) claimed that $\mathrm{C}$-species have low leaf dry matter contents. When we analysed the strategies, we have seen that some species with the $\mathrm{C}$ strategy in the Liman lake have different strategies in the other lakes. Additionally, Liman lake has lower LDW values. For Grime et al. (1989) scheme; $P$. nodosus LDW values are 13.59\% in Liman lake, $15.59 \%$ in Cernek lake and $23.09 \%$ in Balık lake. For Pierce et al. (2013) scheme; P. nodosus LDW values are $13.59 \%$ in Liman lake, $15.61 \%$ in Cenek lake and 23.09\% in Balık lake. However, (Novakovskiy et al., 2016) found that C-strategists have high leaf dry matter contents due to the thickness of leaf cell walls. Our data agreed with both Grime (2002) and Novakovskiy et al. (2016) because C-strategists in Liman lake had low LDW, while C-strategists in Balık lake had high LDW. For example; B. umbellatus LDW value is $15.31 \%$ in Liman lake and $17.07 \%$ in Balık lake. Novakovskiy et al. (2016) also found that C-species had minimal SLA values. Our data supported the data of Novakovskiy et al. (2016) with respect to SLA values. For example; $P$. nodosus SLA values are 8.89 in Liman lake, 20.99 in Cenek lake and 32.62 in Balık lake according to Grime et al. (1989). and Pierce et al. (2013) schemes.

$R$. repens in Liman lake, and $A$. plantago subsp. aquatica in Cernek lake exhibit $C R$ and $C / C R$ strategies considering Grime et al. (1989) and Pierce et al. (2013) schemes (respectively). Greulich \& Bornette (1999) emphasized that CR-strategist species usually show a capacity for rapid vegetative spreading. In this way, they rapidly colonize the temporary gaps and widespread in intermediately disturbed sites. Agricultural facilities, overgrazing and the use of lake water as irrigation water are the main disturbance factors in the study area. Potamogeton species exhibit mostly CR strategy in studied lakes. According to Grime (1979), C-R-strategists are typical in intermediately disturbed sites. Perennial C-R-strategists are "strongly rhizomatous and stoloniferous and show a capacity for rapid vegetative spread" and species of this type are "efficient colonisers of temporary gaps" Greulich \& Bornette (1999). Lehmann et al. (1997) found that Potamogeton species had a high competitive ability, and they have classified as a good competitor for nutrients. Our study is consistent with this information because the strategies calculated according to both schemes are in the C-R strategists.

There were some similarities and dissimilarities regarding ecological strategies between the present study and previous studies. For example, it has been reported that Juncus and Potamogeton species exhibit SR-strategy (Hüseyinova et al., 2013; Pierce et al., 2012). However, J. acutus presents SC and C/SC, C/CSR, according to Grime et al. (1989) and Pierce et al. (2013) schemes, respectively. Potamogeton species exhibit $C$, $\mathrm{C} / \mathrm{CR}, \mathrm{CR}, \mathrm{R}$ and $\mathrm{C}, \mathrm{C} / \mathrm{SC}, \mathrm{C} / \mathrm{CR}, \mathrm{CR}$ according to Grime et al. (1989) and Pierce et al. (2013) schemes in the present study, respectively. Myriophyllum spicatum and Alisma species have seeds that can float for extended periods, sometimes for more than a year, to allow colonization of fresh sites. Nymphaea species have moderate relative growth rates and limited vegetative dispersal and exhibit C-strategy (Pierce et al., 2012). N. alba in Cernek lake and Balık lake exhibit C/CR and C/CSR strategy according to Grime et al. (1989) scheme, respectively. But according to Pierce et al. (2013) scheme, It exhibit C strategy in Cernek lake and SC strategy in Balık lake. It has been reported that many macrophytic species are $R$ selected in the extreme, in keeping with a lifestyle based around rapid regeneration in the face of disturbance.

$R$. trichophyllus, L. minor and $P$. pectinatus L. exhibit R-strategy considering Grime et al. (1989) scheme. It has been stated that ruderal species have a short lifespan, and they usually self-pollinated for increasing reproductive success in disturbed habitats (Šerá \& Šerý, 2004). R-strategy has associated with hydrological instability and in such conditions, competitive species which their ecological strategies are primarily due to their vegetative reproduction (Weyembergh et al., 2004). Amphibious species like Alisma sp. exhibit S- or R- strategies because they prefer vegetative reproduction in refuge areas of water and very tolerant to underwater environmental conditions. Ranunculus species which live in patch like heterogenous areas exhibit similar strategies to Alisma species. It has been found that Alisma plantagoaquatica exhibits CR strategy in Cernek lake, while it exhibits R/CR strategy in Balık lake, according to Grime et al. (1989) scheme. But according to Pierce et al. (2013) scheme, it presents C/CR strategy in both lakes. Dorken \& Barrett (2004) found that different monoecious and dioecious populations of Alismataceae members have different reproductive strategies, and consequently, they exhibit different ecological strategies.

Similarly, Toma (2013) found H. morsus-ranae exhibits SR strategy. However, $H$. morsus-ranae exhibits different strategies in the present study. These are S/CSR in Liman lake and SR in Balık lake, according to Grime et al. (1989) scheme. But according to Pierce et al. (2013) scheme, these are SC in Liman lake and S/SR in Balık lake. H. morsus-ranae could be classified as a competitor species, and its dense, floating mats dominate in the floating vegetation zone (Halpern, 2017). This supported that ecological strategies have been changed due to environmental and local factors (Lacoul \& Freedman, 2006). Therefore, it has been found to have different strategies in lakes with various 
ecological features. Ranunculus species exhibited CR, R and C/CR-strategies considering both schemes and supported the data of Willby et al. (2000) and Hunt et al. (2004).

Some differences were found with respect to plant strategies, according to Pierce et al. (2013) in both species and community level. Kılıç et al. (2018) stated that numerical traits were used in Pierce et al. (2013) scheme and some traits such as flowering time may be changed due to phenological growth period so that Pierce et al. (2013) scheme is more practical.

At the community level, $\mathrm{C} / \mathrm{CR}-\mathrm{C} / \mathrm{SC}$ strategies are found to be dominant Liman lake, CR/CSR - C/CSR strategies are found to be dominant in Cernek lake and C/CSR - C/SC strategies dominant in Balık lake. The hypothesis of intermediate disturbance (Connell, 1978), which means disturbance with intermediate frequency and magnitude, allows fast-growing ruderal species and competitive species to co-occur, favouring a great richness and diversity of species (Arthaud et al., 2012; Trémolières, 2004). Similar differences were also found when plant strategies were evaluated at the community level. Capers et al. (2010) indicated that environmental conditions strongly influence aquatic plants.

It has been found that macrophyte communities in studied lagoons reflect the influence of local conditions and $\mathrm{pH}, \mathrm{EC}, \mathrm{P}$ and $\mathrm{NH}_{4}$ concentrations were found to be significant. CCA revealed that $\mathrm{pH}$ was found to be related to $P$. pectinatus and $P$. nodosus and Alahuhta (2015) found $P$. crispus and $P$. pectinatus were strongly related to alkalinity in some hard water lakes. Total $P$ concentration and EC were found to be associated with emergent macrophytes such as Juncus acutus and Butomus umbellatus. These variables were classified as human disturbancevariables and found to be closely related to emergent macrophytes (Alahuhta et al., 2013). There were connections among studied lakes in the present study, and Capers et al. (2010) stated that such connections contribute to the effect of connectivity on dispersal-related variation. Lacoul \& Freedman (2006) stated that some macrophyte species may are indicators of some chemical traits in lakes. $\mathrm{N}$ concentration in Cernek lake was high during summer and winter, and the existence of Ceratophyllum demersum is evaluated as useful indicators of high nitrogen conditions.

\section{Conclusions}

Secondary and transitional strategies were found to be dominant according to both schemes. S-strategy was not found in studied species following the general trend in aquatic ecosystems. Some of the chemical traits $\left(\mathrm{pH}, \mathrm{EC}, \mathrm{P}\right.$ and $\left.\mathrm{NH}_{4}\right)$ were found to be significant in plant species in studied lakes. Biological diversity was found to be correlated with chemical traits. However, no significant correlations were found between water $P$ concentrations and evenness. Intermediate disturbance hypothesis was found to be valid in studied lakes similar to other aquatic ecosystems. There were some similarities and dissimilarities regarding ecological strategies between the present study and previous studies because macrophytes show a range of ecotypes within a short distance due to their phenotypic plasticity.

\section{Ethical Statement}

Not applicable.

\section{Funding Information}

The authors received no financial support for the research, authorship, and/or publication of this article.

\section{Authors' Contributions}

HGK conceived and designed the research. $\mathrm{HB}$ and BS: performed the field work, laboratuar work and statistical analyses. All authors contributed to the writing of the article.

\section{Conflict of Interest} interest.

The authors declare that they have no conflict of

\section{Acknowledgements}

We would like to acknowledge Ahmet Ridvan Topkara and Elif Topkara for assisting with field survey.

\section{References}

Agır, S.U., Kutbay, H.G., Karaer, F., \& Surmen, B. (2014). The classification of coastal dune vegetation in Central Black Sea Region of Turkey by numerical methods and EU habitat types. Rendiconti Lincei, 25(4), 453-460. https://doi.org/10.1007/s12210-014-0328-7

Agır, S.U., Kutbay, H.G., \& Surmen, B. (2016). Plant diversity along coastal dunes of the Black Sea (North of Turkey). Rendiconti Lincei, 27(3), 443-453. https://doi.org/10.1007/s12210-015-0497-z

Alahuhta, J. (2015). Geographic patterns of lake macrophyte communities and species richness at regional scale. Journal of Vegetation Science, 26(3), 564-575. https://doi.org/10.1111/jvs.12261

Alahuhta, J., Kanninen, A., Hellsten, S., Vuori, K.-M., Kuoppala, M., \& Hämäläinen, H. (2013). Environmental and spatial correlates of community composition, richness and status of boreal lake macrophytes. Ecological Indicators, 32, 172-181. https://doi.org/10.1016/j.ecolind.2013.03.031

Alahuhta, J., Kosten, S., Akasaka, M., Auderset, D., Azzella, M.M., Bolpagni, R., Bove, C.P., Chambers, P.A., Chappuis, E., Clayton, J., de Winton, M., Ecke, F., Gacia, E., Gecheva, G., Grillas, P., Hauxwell, J., Hellsten, S., Hjort, J., Hoyer, M.V., ... Heino, J. (2017). Global variation in the beta diversity of lake macrophytes is driven by environmental heterogeneity rather than latitude. 
Journal of Biogeography, 44(8), 1758-1769. https://doi.org/10.1111/jbi.12978

Arthaud, F., Vallod, D., Robin, J., \& Bornette, G. (2012). Eutrophication and drought disturbance shape functional diversity and life-history traits of aquatic plants in shallow lakes. Aquatic Sciences, 74(3), 471-481. https://doi.org/10.1007/s00027-011-0241-4

Berger, W.H., \& Parker, F.L. (1970). Diversity of Planktonic Foraminifera in Deep-Sea Sediments. Science, 168(3937), 1345-1347. https://doi.org/10.1126/science.168.3937.1345

Bilgin, A., Yalcin, E., Kutbay, H.G., \& Kilinc, M. (2003). Nutrient concentrations and biomass in lake vegetation and nutrient limitation in lakes of Northern Black Sea Region of Turkey. Ekologia Bratislava, 3(22), 257-268.

Bolpagni, R., Laini, A., Stanzani, C., \& Chiarucci, A. (2018). Aquatic Plant Diversity in Italy: Distribution, Drivers and Strategic Conservation Actions. Frontiers in Plant Science, 9(116). https://doi.org/10.3389/fpls.2018.00116

Brown, L.R., Du Preez, P.J., Bezuidenhout, H., Bredenkamp, G.J., Mostert, T.H.C., \& Collins, N.B. (2013). Guidelines for phytosociological classifications and descriptions of vegetation in southern Africa. Koedoe, 55(1), Art. \#1103. https://doi.org/10.4102/koedoe.v55i1.1103

Can, Ö., \& Taş, B. (2012). Ramsar Alanı İçinde Yer Alan Cernek Gölü ve Sulak Alanın (Kızılırmak Deltası, Samsun) Ekolojik ve Sosyo-Ekonomik Önemi. TÜBAV Türk Bilim Araştırması Dergisi, 5, 1-11.

Capers, R.S., Selsky, R., \& Bugbee, G.J. (2010). The relative importance of local conditions and regional processes in structuring aquatic plant communities. Freshwater Biology, 55(5), 952-966.

https://doi.org/10.1111/j.1365-2427.2009.02328.x

Carvalho, F., Brown, K.A., Waller, M.P., Razafindratsima, O.H., \& Boom, A. (2020). Changes in functional, phylogenetic and taxonomic diversities of lowland fens under different vegetation and disturbance levels. Plant Ecology, 221(6), 441-457. https://doi.org/10.1007/s11258-020-01024-1

Chappuis, E., Gacia, E., \& Ballesteros, E. (2014). Environmental factors explaining the distribution and diversity of vascular aquatic macrophytes in a highly heterogeneous Mediterranean region. Aquatic Botany, 113, 72-82. https://doi.org/10.1016/j.aquabot.2013.11.007

Chave, J., Navarrete, D., Almeida, S., Álvarez, E., Aragão, L.E.O.C., Bonal, D., Châtelet, P., Silva-Espejo, J.E., Goret, J.-Y., von Hildebrand, P., Jiménez, E., Patiño, S., Peñuela, M.C., Phillips, O.L., Stevenson, P., \& Malhi, Y. (2010). Regional and seasonal patterns of litterfall in tropical South America. Biogeosciences, 7(1), 43-55. https://doi.org/10.5194/bg-7-43-2010

Christia, C., Giordani, G., \& Papastergiadou, E. (2018). Environmental Variability and Macrophyte Assemblages in Coastal Lagoon Types of Western Greece (Mediterranean Sea). Water, 10(2), 151. https://doi.org/10.3390/w10020151

Chytrý, M., Tichý, L., \& Roleček, J. (2003). Local and regional patterns of species richness in Central European vegetation types along the $\mathrm{pH} / \mathrm{calcium}$ gradient. Folia Geobotanica, 38(4), 429-442. https://doi.org/10.1007/BF02803250

Connell, J.H. (1978). Diversity in Tropical Rain Forests and Coral Reefs. Science, 199(4335), 1302-1310. https://doi.org/10.1126/science.199.4335.1302
Dorken, M.E., \& Barrett, S.C.H. (2004). Phenotypic plasticity of vegetative and reproductive traits in monoecious and dioecious populations of Sagittaria latifolia (Alismataceae): a clonal aquatic plant. Journal of Ecology, 92(1), 32-44. https://doi.org/10.1111/j.13652745.2004.00857.x

DSI. (2017). General Directorate of State Hydraulic WorksData.

Ersanli, E., \& Gonulol, A. (2007). Epiphytic diatoms on Cladophora rivularis (Linnaeus) Hoek (Chlorophyta) and Potamogeton pectinatus Linnaeus (Spermatophyta) in lake Simenit (Samsun-Turkey). Diatom Research, 22(1), 27-44. https://doi.org/10.1080/0269249X.2007.9705693

Ersanli, E., \& Gönülol, A. (2006). A study on the phytoplankton of Lake Simenit, Turkey. Cryptogamie, Algologie, 27(3), 289-305.

Eskandari, A. (2014). Türkiye'de Kıyısal ve Karasal Tuzlu Göllerde Yayılım Gösteren Artemia Populasyonlarının Ekolojik, Sitogenetik, Moleküler, Morfomometrik Yöntemler Kullanılarak Araştırılması ve Biyotopların Hidrobiyolojik Yönden Incelenmesi. Hacettape Üniversitesi.

Gaberščik, A., Krek, J.L., \& Zelnik, I. (2018). Habitat diversity along a hydrological gradient in a complex wetland results in high plant species diversity. Ecological Engineering, 118, 84-92. https://doi.org/10.1016/j.ecoleng.2018.04.017

Garbey, C., Thiébaut, G., \& Muller, S. (2004). Morphological plasticity of a spreading aquatic macrophyte, Ranunculus peltatus, in response to environmental variables. Plant Ecology (Formerly Vegetatio), 173(1), 125-137. https://doi.org/10.1023/B:VEGE.0000026336.44576.ff

Greulich, S., \& Bornette, G. (1999). Competitive abilities and related strategies in four aquatic plant species from an intermediately disturbed habitat. Freshwater Biology, 41(3), 493-506. https://doi.org/10.1046/j.13652427.1999.00395.x

Grime, J.P. (1979). Plant strategies and vegetation processes. John Wiley \& Sons.

Grime, J.P. (2002). Plant Strategies, Vegetation Processes, and Ecosystem Properties. John Wiley \& Sons.

Grime, J.P., Hodgson, J.G., \& Hunt, R. (1989). Comparative plant ecology: a functional approach to common British species. Springer. https://doi.org/10.1007/978-94-0141094-7

Halpern, A.D. (2017). Hydrocharis morsus-ranae L. In the upper st. Lawrence river in new york: its success within heterogenous wetland habitat and potential management approaches. State University of New York.

Henderson, P.A., \& Seaby, R.M.H. (1999). Community analysis package (1.33). Pisces Conservation Ltd.

Higuti, J., Velho, L.F.M., Lansac-Tôha, F.A., \& Martens, K. (2007). Pleuston communities are buffered from regional flood pulses: the example of ostracods in the Paraná River floodplain, Brazil. Freshwater Biology, 52(10), 1930-1943. https://doi.org/10.1111/j.13652427.2007.01821.x

Hodgson, J.G., Wilson, P.J., Hunt, R., Grime, J.P., \& Thompson, K. (1999). Allocating C-S-R Plant Functional Types: A Soft Approach to a Hard Problem. Oikos, 85(2), 282. https://doi.org/10.2307/3546494

Hunt, R., Hodgson, J.G., Thompson, K., Bungener, P., Dunnett, N., \& Askew, A. (2004). A new practical tool for deriving a functional signature for herbaceous vegetation. Applied Vegetation Science, 7(2), 163-170. 
https://doi.org/10.1111/j.1654-109X.2004.tb00607.x

Hüseyinova, R., Kılınc, M., Kutbay., H.G., Kilic, D.D., \& Bilgin, A. (2013). The comparison of Grime? s strategies of plant taxa in Hacı Osman Forest and Bafra Fish Lakes in Central Black Sea Region of Turkey. TURKISH JOURNAL OF BOTANY, 37(4), 725-734. https://doi.org/10.3906/bot1112-33

IBM, C. (2012). IBM SPSS statistics for windows (No. 21). IBM Corporation.

Kattge, J., Díaz, S., Lavorel, S., Prentice, I.C., Leadley, P., Bönisch, G., Garnier, E., Westoby, M., Reich, P.B., Wright, I.J., Cornelissen, J.H.C., Violle, C., Harrison, S.P., van Bodegom, P.M., Reichstein, M., Enquist, B.J., Soudzilovskaia, N.A., Ackerly, D.D., Anand, M., ... Wirth, C. (2011). TRY - a global database of plant traits. Global Change Biology, 17(9), 2905-2935. https://doi.org/10.1111/j.1365-2486.2011.02451.x

Kautsky, L. (1988). Life Strategies of Aquatic Soft Bottom Macrophytes. Oikos, 53(1), 126. https://doi.org/10.2307/3565672

Kennedy, M.P., \& Murphy, K.J. (2003). Hydrological and hydrochemical conditions characterising Carex chordorrhiza L. fil. (String Sedge) habitat in a Scottish riverine floodplain wetland. Aquatic Botany, 77(4), 243255. https://doi.org/10.1016/S0304-3770(03)00107-4

Kılıç, D.D., Kutbay, H.G., Sürmen, B., \& Hüseyinoğlu, R. (2018). The classification of some plants subjected to disturbance factors (grazing and cutting) based on ecological strategies in Turkey. Rendiconti Lincei. Scienze Fisiche e Naturali, 29(1), 87-102. https://doi.org/10.1007/s12210-017-0664-5

Lacoul, P., \& Freedman, B. (2006). Environmental influences on aquatic plants in freshwater ecosystems. Environmental Reviews, 14(2), 89-136. https://doi.org/10.1139/a06001

Lehmann, A., Castella, E., \& Lachavanne, J.-B. (1997). Morphological traits and spatial heterogeneity of aquatic plants along sediment and depth gradients, Lake Geneva, Switzerland. Aquatic Botany, 55(4), 281-299. https://doi.org/10.1016/S0304-3770(96)01078-9

Lukács, B.A., Vojtkó, A.E., Mesterházy, A., Molnár V.A., Süveges, K., Végvári, Z., Brusa, G., \& Cerabolini, B.E.L. (2017). Growth-form and spatiality driving the functional difference of native and alien aquatic plants in Europe. Ecology and Evolution, 7(3), 950-963. https://doi.org/10.1002/ece3.2703

Magurran, A.E., \& Mc Gill, B.J. (2011). Biological Diversity. Oxford University Press.

McCarthy, B.C., \& Magurran, A.E. (2004). Measuring Biological Diversity. Journal of the Torrey Botanical Society, 131(3), 277. https://doi.org/10.2307/4126959

McCoy-Sulentic, M.E., Kolb, T.E., Merritt, D.M., Palmquist, E.C., Ralston, B.E., \& Sarr, D.A. (2017). Variation in specieslevel plant functional traits over wetland indicator status categories. Ecology and Evolution, 7(11), 3732-3744. https://doi.org/10.1002/ece3.2975

Metian, M., Troell, M., Christensen, V., Steenbeek, J., \& Pouil, S. (2020). Mapping diversity of species in global aquaculture. Reviews in Aquaculture, 12(2), 1090-1100. https://doi.org/10.1111/raq.12374

Morkoyunlu Yüce, A., Gönülol, A., \& Gezgin Demir, E. (2017). Fener Gölü'nün Bazı Hidrobiyolojik Özellikleri (Kocaeli/Türkiye). Research Journal of Biology Sciences, 10(1), 26-32.

Murphy, K.J., Rørslett, B., \& Springuel, I. (1990). Strategy analysis of submerged lake macrophyte communities: an international example. Aquatic Botany, 36(4), 303-323. https://doi.org/10.1016/0304-3770(90)90048-P

Novakovskiy, A.B., Maslova, S.P., Dalke, I.V., \& Dubrovskiy, Y.A. (2016). Patterns of Allocation CSR Plant Functional Types in Northern Europe. International Journal of Ecology, 2016, 1-11.

https://doi.org/10.1155/2016/1323614

Özdemir, C.D. (2019). Balık Gölü’nün (Bafra Balık Gölleri, Kizilirmak Deltasi) Zooplanktonik Organizmalarinin Mevsimsel Değişimi Üzerine Ekolojik Araştirmalar. Hacettepe Üniversitesi.

Ozturk, D., Beyazit, I., \& Kilic, F. (2015). Spatiotemporal Analysis of Shoreline Changes of the Kizilirmak Delta. Journal of Coastal Research, 316, 1389-1402. https://doi.org/10.2112/JCOASTRES-D-14-00159.1

Pierce, S., Brusa, G., Sartori, M., \& Cerabolini, B.E.L. (2012). Combined use of leaf size and economics traits allows direct comparison of hydrophyte and terrestrial herbaceous adaptive strategies. Annals of Botany, 109(5), 1047-1053.

https://doi.org/10.1093/aob/mcs021

Pierce, S., Brusa, G., Vagge, I., \& Cerabolini, B.E.L. (2013). Allocating CSR plant functional types: the use of leaf economics and size traits to classify woody and herbaceous vascular plants. Functional Ecology, 27(4), 1002-1010. https://doi.org/10.1111/1365-2435.12095

Pierce, S., Negreiros, D., Cerabolini, B.E.L., Kattge, J., Díaz, S., Kleyer, M., Shipley, B., Wright, S.J., Soudzilovskaia, N.A., Onipchenko, V.G., van Bodegom, P.M., FrenetteDussault, C., Weiher, E., Pinho, B.X., Cornelissen, J.H.C., Grime, J.P., Thompson, K., Hunt, R., Wilson, P.J., ... Tampucci, D. (2017). A global method for calculating plant "CSR" ecological strategies applied across biomes world-wide. Functional Ecology, 31(2), 444-457. https://doi.org/10.1111/1365-2435.12722

Riis, T., \& Biggs, B.J.F. (2001). Distribution of macrophytes in New Zealand streams and lakes in relation to disturbance frequency and resource supply-a synthesis and conceptual model. New Zealand Journal of Marine and Freshwater Research, 35(2), 255-267. https://doi.org/10.1080/00288330.2001.9516996

Rodríguez-Gallego, L., Sabaj, V., Masciadri, S., Kruk, C., Arocena, R., \& Conde, D. (2015). Salinity as a Major Driver for Submerged Aquatic Vegetation in Coastal Lagoons: a Multi-Year Analysis in the Subtropical Laguna de Rocha. Estuaries and Coasts, 38(2), 451-465. https://doi.org/10.1007/s12237-014-9842-1

Roleček, J., Tichý, L., Zelený, D., \& Chytrý, M. (2009). Modified TWINSPAN classification in which the hierarchy respects cluster heterogeneity. Journal of Vegetation Science, 20(4), 596-602. https://doi.org/10.1111/j.16541103.2009.01062.x

Schuster, B., \& Diekmann, M. (2003). Changes in species density along the soil $\mathrm{pH}$ gradient - evidence from German plant communities. Folia Geobotanica, 38(4), 367-379. https://doi.org/10.1007/BF02803245

Šerá, B., \& Šerý, M. (2004). Number and weight of seeds and reproductive strategies of herbaceous plants. Folia Geobotanica, 39(1), 27-40. https://doi.org/10.1007/BF02803262

Smith, B., \& Wilson, J.B. (1996). A Consumer's Guide to Evenness Indices. Oikos, 76(1), 70. https://doi.org/10.2307/3545749

Sürmen, B., Ulu Ağır, Ş., \& Kutbay, H.G. (2019). Rare dune plant 
species in Samsun Provience, Turkey. Anatolian Journal of Botany, 3(2), 34-39.

https://doi.org/10.30616/ajb.551995

Toma, C. (2013). Reproduction of Hydrocharis morsus-ranae taxa in an oxbow lake of the River Vistula. Limnological Review, 13(3), 171-179. https://doi.org/10.2478/limre2013-0019

Trémolières, M. (2004). Plant response strategies to stress and disturbance: the case of aquatic plants. Journal of Biosciences, 29(4), 461-470. https://doi.org/10.1007/BF02712119

Tyrrell, C.D. (2015). The utility of growth form for predicting and evaluating aquatic plant nutrient relations. The University of New Brunswick.

Van Der Maarel, E. (1979). Transformation of coverabundance values in phytosociology and its effects on community similarity. Vegetatio, 39(2), 97-114. https://doi.org/10.1007/BF00052021

Westoby, M., \& Wright, I.J. (2006). Land-plant ecology on the basis of functional traits. Trends in Ecology \& Evolution, 21(5), 261-268.

https://doi.org/10.1016/j.tree.2006.02.004

Weyembergh, G., Godefroid, S., \& Koedam, N. (2004). Restoration of a small-scale forest wetland in a Belgian nature reserve: a discussion of factors determining wetland vegetation establishment. Aquatic Conservation: Marine and Freshwater Ecosystems, 14(4), 381-394. https://doi.org/10.1002/aqc.623

Willby, N.J., Abernethy, V.J., \& Demars, B.O.L. (2000). Attribute-based classification of European hydrophytes and its relationship to habitat utilization. Freshwater Biology, 43(1), 43-74. https://doi.org/10.1046/j.13652427.2000.00523.x

Wright, I.J., Groom, P.K., Lamont, B.B., Poot, P., Prior, L.D., Reich, P.B., Schulze, E.-D., Veneklaas, E.J., \& Westoby, M. (2004). Short Communication: Leaf trait relationships in Australian plant species. Functional Plant Biology, 31(5), 551. https://doi.org/10.1071/FP03212

Wu, H., Carrillo, J., \& Ding, J. (2016). Invasion by alligator weed, Alternanthera philoxeroides, is associated with decreased species diversity across the latitudinal gradient in China. Journal of Plant Ecology, 9(3), 311319. https://doi.org/10.1093/jpe/rtv060

Wu, H., Carrillo, J., \& Ding, J. (2017). Species diversity and environmental determinants of aquatic and terrestrial communities invaded by Alternanthera philoxeroides. Science of The Total Environment, 581-582, 666-675. https://doi.org/10.1016/j.scitotenv.2016.12.177

Wu, H., \& Ding, J. (2020). Abiotic and Biotic Determinants of Plant Diversity in Aquatic Communities Invaded by Water Hyacinth [Eichhorniacrassipes (Mart.) Solms]. Frontiers in Plant Science, 11. https://doi.org/10.3389/fpls.2020.01306

Yalçin, E., Bilgin, A., Kutbay, H.G., \& Kilinç, M. (2004). Relationships between community structure and soil properties of a swamp forest from Northern Turkey. Polish Journal of Ecology, 52(2), 233-238. 